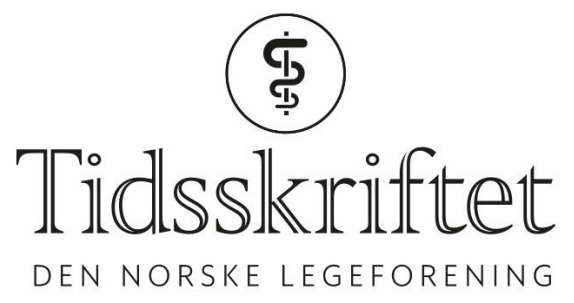

\title{
Rettelse: Kraftig stigning i kreatinkinase etter intensiv trening
}

RETTELSE

ESKILD SKOV PEDERSEN

SINDRE TENGESDAL

MARIA RADTKE

KNUT ASBJØRN RISE LANGLO

Tidsskr Nor Legeforen 2019; 139: 613-6.

I Tidsskriftet nr. 7/2019 på s. 613 og 615 skal forfatternavnet være Maria Radtke.

Vi beklager feilen, den er rettet på nett.

Publisert: 25. april 2019. Tidsskr Nor Legeforen. DOI: 10.4045/tidsskr.19.0291

(C) Tidsskrift for Den norske legeforening 2020. Lastet ned fra tidsskriftet.no 